\title{
MOŠKA DOMINACIJA PIERRA BOURDIEUJA
}

Ključne besede: moška dominacija, epistemocentrizem, začarani krog legitimnosti, habitus, polje

Pisanje $^{1}$ o tako »težkem delu, kot je Bourdiejevo «(Pinto, 2002,244), pušča mnoga vprašanja in odgovore ob strani. Tudi Bourdieu v Preambuli $\mathrm{k}$ Moški dominaciji, pove, da se niti sam ne bi soočil s tako težko temo, če ne bi bil v to prisiljen spričo narave svojega raziskovanja.

Sama sem izbrala zgolj epistemološki vidik nekaterih vprašanj moške dominacije, za katera menim, da predstavljajo najpomembnejši Bourdiejev prispevek $\mathrm{k}$ feministični teoriji v sociologiji. Ta vprašanja bi lahko formulirali takole:

Če velja, da se moška dominacija kljub feminističnim bojem še vedno vzdržuje in ohranja v spremembah, podrejenost žensk pa se vrača, kje se tedaj nahajajo glavni družbeni determinizmi podrejenega položaja žensk? S pomočjo katerih mehanizmov se skozi stoletja vzdržuje svetovna ureditev moške dominacije oziroma $\mathrm{v}$ čem je posebnost legitmnosti moške dominacije? Kako pride do popolnega preobrata vzroka in posledice, da družbeno postane naravno? Kateri so dejavniki njenega trajanja in reproduciranja? Zgodovinsko ozadje vseh teh vprašanj po Bourdieuju predstavlja sicer zamolčano vprašanje o zgodovinskem delu, ki je nepogrešljivo, če hočemo moško dominacijo, mehanizme in akcije, ki so odgovorni za njeno dehistorizacijo, izluščiti iz zgodovine (Bourdieu, 1998,110).

1 Na tem mestu se želim zahvaliti prof. dr. Milici Antič-Gaber za povabilo, da pripravim ta prispevek. 
Vendar pa je nujno, preden odgovorimo na ta vprašanja, pokazati na epistemocentrizem znotraj sociologije.

Sociologija je bila, tako kot tudi mnoge druge družbene vede, moškocentrična znanost. Bourideu v svojem članku o Marcelu Maussu citira njegove besede, za katere sicer meni, da hkrati predstavljajo »bilanco« in program: »Naša sociologija je $\mathrm{v}$ tem ( $\mathrm{t}$. kar zadeva delitev po spolu) zelo inferiorna $\mathrm{v}$ odnosu na to, kar bi morala biti. Tako smo osnovali zgolj moško sociologijo, ne pa tudi ženske sociologije, ali sociologije obeh spolov«. (Mauss 1932, 1969:15). Te besede brez nadaljnjega analiziranja s prstom pokažejo na radikalno obliko etnocentrizma, ki ni nič drugega kot epistemocentrizem, iluzija, pri kateri ne gre zgolj za uporabo kategorij mišljenja, ki so sestavni del naše akademske »mentalitete«, temveč bi lahko celo trdili, da te besede $\mathrm{v}$ sociologijo uvajajo homo academicusa kot predhodnika vsake sociologije (Bourdieu, 2004).

Danes ne najdemo nobenega znanega sociologa, ki se ne bi ukvarjal s to problematiko, oziroma sociologa, ki ne more mimo tega, da se ne bi ukvarjal s to problematiko. Če poleg Bourdieuja omenim še Giddensa, Derridaja, Touraina in Becka, bi lahko dejala, da postaja problematika žensk sestavni del »normalne« (v Kuhnovem pomenu) sociologije, kar že samo po sebi lahko vodi do preizpraševanja potrebe po študijah spola in ženskih študi$\mathrm{jah}^{2}$.

Kako se Bourdieu poskuša izogniti oz. rešiti ta epistemocentrizem sociologije? »Po Bourdieujevih besedah je moškim težko pisati o tej temi iz dveh razlogov: dominacija se nanaša na ženske, one jo občutijo... in nikoli ne moreš biti zares prepričan, da si prišel do dna skrivnostim teh nezavednih struktur, preko katerih se ta dominacija izvaja « (Forum Pierre Bourdieu, 1998). Tudi Alain Touraine v Uvodu k Svetu žensk pravi: »Kot moški si nisem drznil napisati knjige, ki bi neposredno razpravljala o ženskah, njihovih stališčih, izkušnjah. To pa ne le zato, ker bi menil, da zgolj enaki lahko preučujejo enake, kar bi bilo absurdno, temveč zato, ker se v primerjavi z žensko težje znajdem $v$ tem ženskem svetu, ki je tako temeljito prou-

2 O vprašanju ali študije spola ali ženske študije več v: M. Filipović, 2000, „Studije roda: dilema, izazov, mogućnost, na Univerzitetu Crne Gore«, Zbornik Pravnog fakulteta u Podgorici št. 31, str. 31-37. 
čevan « (Touraine, 2006,10). Dandanes mnoge ženske zaradi golega dejstva, da so ženske, menijo, da so za vse, kar je vezano na žensko problematiko, kompetentnejše od moških. Ali gre tu za to, kar Donna Haraway imenuje epistemologija »identitete«, ki s stališča strokovnjakov (ali iz kakega drugega stališča, na primer žensk ali podrejenih) vidi tisto, kar mora videti (Haraway, 1988). V obzir je potrebno vzeti razliko med običajnim, zdravorazumskim znanjem in znanstveno vednostjo, ki jo je v sociologiji utemeljil že Durkheim. Vendar se pri tem vprašanju ne bomo zadrževali.

Bourdieu se poskuša izogniti temu epistemocentrizmu s pomočjo znanstvene objektivnosti. Tako gre po poti Clauda Lévi-Straussa in proučuje »kategorije dojemanja« ali oblike klasifikacije, da analizira skrivnosti nezavedne strukture, s pomočjo katerih se dominacija izvaja. Miselne strukture kabilske družbe oziroma moškocentrične oblike nezavednega pri Berberih mu služijo kot delovni instrument. Preko teh izpelje objektivizacijo kategorij tega nezavednega, ki je skupno vsem mediteranskim družbam (Bourdieu, 1998, 11-12). Te kategorije nezavednega so tudi danes deloma prisotne kot odsev v naših miselnih in družbenih strukturah. Etnološki opis družbenega sveta, s katerim Bourdieu začne dokazovati svojo trditev o moškidominaciji, je »dovolj oddaljen, da je lahko predmet lažje objektivizacije« (Bourdieu, 2001). To ga opogumi, da svoje raziskovanje usmeri "na objektivno arheologijo našega nezavednega«. Da bi bila objektivnost tega raziskovanja mogoča, moramo, kot pravi Bourdieu v Preambuli, nujno razbiti varljiv odnos pristnosti, ki nas združuje z lastno tradicijo (Bourdieu, 1998, 9). Z drugimi besedami, potrebno je ustvariti spoznavno distanco do predmeta preiskovanja.

Toda Bourdieu kasneje, v svojem zadnjem predavanju, ki je objavljeno v knjigi Science de la science et réflexivite ${ }^{3}$, močneje poudari, da je posebnost družbenih znanosti dvakratna družbena konstrukcija, da je potrebno razsvetliti tisto, kar je skrito, tisto, kar se izmika pogledu znanosti, saj se skriva v samem pogledu strokovnjaka: nezavedno transcendentalno. Družbene vede bomo iztrgali iz procesa relativizacije, če se bomo lotili lastne zavesti.

3 Bourdieu, Pierre, 2001, Science de la science et réflexivité, Raison D`agir., Pariz. (Op.prev.: Slovenski prevod: Bourdieu, P., 2004: Znanost o znanosti in refleksivnost. Liberalna akademija, Ljubljana.) 
Ta zgodovinski transcendentalizem, to zgodovinsko nezavedno je vpisano v možgane znanstvenika - v znanstveni habitus - in v družbene pogoje, znotraj katerih sam proizvaja (znanstveno polje) konstrukcije» (Bourdieu, $2001,173)$. To pomeni, da mora sociologija, če hoče biti objektivna in če se hoče iztrgati iz relativizacije, vzeti za predmet preiskovanja samo sebe (da ozavesti nezavedno transcendentalno ali zgodovinski transcendentalizem), da objektivizira subjekt objektivizacije. Ta proces pomaga Bourdieuju, da pride do dna zgodovinskemu delu dehistorizacije.

Poleg te epistemološke problematike je v tem uvodnem delu potrebno poudariti, da pojem polja zavzema osrednje mesto $\mathrm{v}$ njegovi sociologiji. Družbeni prostor je sestavljen iz pluralizma samostojnih polj. Polje je področje družbenega življenja, ki se je postopoma osamosvajalo okrog družbenih odnosov. Govorimo lahko o ekonomskem, pravnem, filozofskem, književnem, športnem, šolskem, znanstvenem in drugih poljih. Strukturo polja narekuje položaj različnih agensov, ki se borijo za prisvajanje kapitala, ki je lasten danemu polju. $\mathrm{V}$ teh poljih različni družbeni agensi »tečejo« $\mathrm{v}$ različnih prostorih/časih. Polje je prostor, v katerem obstajajo odnosi moči: nevidne strukture vladajočih in podrejenih. Polje je struktura objektivnih odnosov dominacije ali podrejenosti, dopolnjevanja ali nasprotovanja med položaji. Pripomnila bi, da Bourdieu ta pojem v Moški dominaciji zelo redko uporabi, verjetno zato, ker govori o ureditvi sveta, moška dominacija pa prehaja skozi vsa polja in vse oblike moči.

Vsakemu polju ustreza habitus: sistem trajnih in prenosljivih dispozicij. Sociološka misel je od Durkheima do Bourdieuja poskušala preseči dualizme, ki nasproti postavljajo družbo in posameznika, objektivizem in subjektivizem, strukturo in prakso, misel in akcijo. Vendar ji je to v toku lastne zgodovine različno uspevalo.

Teorija habitusa je odkrivanje zunanjosti v jedru notranjosti, odkrivanje družbeno individualnega: družbenega, ki je prelomljeno v individualnem telesu; družbene stvarnosti v njeni utelešeni, interiorizirani, ponotranjeni obliki; preučevanje individuuma kot sestavljenega proizvoda številnih procesov družinske, religijske, šolske, prijateljske, politične socializacije. »Kot izraz socializirane subjektivnosti pojem habitusa predstavlja ključ za preseganje alternative posameznik/družba, v kolikor pomeni govoriti o habitusu 
poudarjati, da je individualno in celo osebno, subjektivno, družbeno, kolektivno« (Bourdieu, Wacqant, 1992, 21). S habitusom se skupnost razkriva $\mathrm{v}$ jedru individualnosti $\mathrm{v}$ obliki kulture.

Ali pojem habitusa dovoljuje misliti individualno posebnost, identiteto osebnosti? Preko Ricoeurjevega razlikovanja objektivne (la mêmeté) in subjektivne (l’ipséité) dimenzije identitete Corcuf pokaže tako na prispevek, kot tudi na omejenost sociološkega problematiziranja habitusa. Prva dimenzija odgovarja na vprašanje: Kdo sem jaz? Ta določa kontinuiteto; »značaj« osebnosti je razumljen kot skupek trajnih dispozicij, po katerih se neka oseba prepozna. Ta kot del objektivne identitete pripada sociologiji, predvsem s pojmom habitusa, ki ga je Bourdieu definiral kot »sistem trajnih in prenosljivih dispozicij«, ki jih posameznik ponotranji tekom svojega življenja. Druga dimenzija je neka vrsta subjektivnega dela osebnostne identitete, katere funkcija je edinstvenost: biti sam svoj zase, pripisati si identiteto (Corcuf, 1999, 95-121).

Skladno s svojo episemološko pozicijo daje Bourdieu primat objektivni dimenziji osebnostne identitete: habitus se ne nanaša na čisto subjektivnost, temveč izraža tudi prisotnost objektivnosti, tj. prisotnost družbeno konstruiranih struktur v subjektivnem izkustvu. Bourdieu subjektivno dimenzijo identitete obravnava kot oviro za znanstveno analizo, kot »biografsko iluzijo «, ki je fiktiven način, s katerim posameznik predstavlja kontinuiteto svoje osebnosti.

Toda vrnimo se $\mathrm{k}$ »zamolčanemu« vprašanju, njegovi zgodovinski dimenziji (1), družbeni konstrukciji (2) in legitimnosti moške dominacije (3).

1. Moč moških je stvar daljšega časovnega obdobja, v katerem se je ta institucionalizirala $\mathrm{v}$ jeziku (moški in ženski spol), v interakcijah (v katerih se prav tako odražajo odnosi moči), v vrednotah (ki so temelj ideologije spola, spolne identitete in vsake legitimnosti, ocenjevanja in samoocenjevanja), v normah (obrednih, religijskih, moralnih, pravnih, ...), v književnosti (nekoč: epska/moška in lirska/ženska; danes: žensko in moško pisanje, v znanosti (mehke/družbene/ženske in trde/naravne/moške), v naših vsakdanjih praksah. Objektivna struktura delitve po spolu oziroma spolnih habitusih je utelešena v našem načinu percepcije, mišljenja in ocenjevanja. Strukturira v obliki nasprotij ali razlik, ne samo v razlikah med telesom, 
gestami, položaji, aktivnostmi, prehrambenimi navadami, poljedelskimi opravili, prostorom in časom ter religijskimi praksami, temveč se razprostira na vsa področja vsakdanjega življenja.

Moška moč se je utelesila v naše zgodovinsko nezavedno v oblikah struktur, ki so prisotne že dalj časa in ki jih preprosto ne moremo uničiti $\mathrm{z}$ voljo in ozaveščenostjo. ${ }^{4}$

2. Družbena določitev telesa je družbena konstrukcija. Telesa so naturalizirana družbena konstrukcija. Z ogromnim kolektivnim delom socializacije se utelesijo karakteristične identitete, ki jih kulturna samovolja oblikuje v jasno ločene spolne habituse (Bourdieu, 1998, 29).

Kako je prišlo do naturaliziranja te družbene konstrukcije? Moški red je vpisan v stvari; red se vpisuje v telesa preko zamolčanih pravil, ki so prisotna pri delitvi dela, skozi vsiljena pravila. Bourdieu meni, da je potrebno razumeti postopek in izpostaviti družbeno konstrukcijo miselnih struktur, ki organizirajo in urejajo konstrukcijo sveta in njegove moči. Pri tem izhaja iz praktične konstrukcije, saj je divja misel Clauda Lévi-Straussa dejansko praktična misel pri Bourdieuju. Priznanje dominacije je vedno neko dejanje spoznanja, pravi Bourdieu, in vsak odnos dominacije ima močno potrebo po izobraževalni dimenziji, da bi jo opravičilo, kar pa ne pomeni, da čaka žensko osvoboditev kot avtomatična posledica »spoznanja«, saj bi to pomenilo zaprtje osvoboditve žensk v filozofijo zavesti. Po Bourdieuju se simbolno nasilje vzpostavlja s posredovanjem odobravanja, katerega podrejeni vladajočim ne morejo odreči, saj lahko svoj odnos do slednjih mislijo zgolj z njim razpoložljivimi instrumenti spoznanja, ki pa so jim skupni (Bourdieu, 1998, 41). Popolnoma iluzorno je verjeti, da se lahko simbolno nasilje premaga $\mathrm{z}$ »dviganjem zavesti« in voljo, kakor imamo pogosto priložnost slišati, saj so posledice in predpostavke njegove učinkovitosti trajno vpisane $\mathrm{v}$ najvišjo telesno intimo na način dispozicij, zaradi česar preživijo izginjanje lastnih družbenih pogojev proizvodnje (Bourdieu, 1998, 45). Dispozicije so neodtujljive od struktur, ki jih proizvajajo, kar velja tako za moške kot za ženske. Dispozicije niso vpisane v naravo, ampak so nujno skonstruirane

4 Nekatere primere teh razlik iz našega vsakdanjega življenja sem prikazala v Društvenoj moći žena u Crnoj Gori. 
$\mathrm{s}$ pomočjo dolgotrajnega dela socializacije, tj. $\mathrm{z}$ aktivnim razlikovanjem $\mathrm{v}$ odnosu do nasprotnega spola (Bourdieu, 1998, 55).

3. Razbitje »začaranega kroga legitimnosti«.

Na spoznavni ravni je posebnost legitimnosti moške dominacije povezana z objektivizmom. Bourdieu se ne zadovolji s trditvijo, da je legitimnost utemeljena v naravi ženske, pa čeprav je ta narava družbena konstrukcija, pač pa preko spoznavne analize nakazuje na mehanizme njenega nastanka, na njeno nevidnost, na popoln obrat vzrokov in posledic, ko družbeno postane naravno, in na njeno reprodukcijo preko habitusa, na soudeležbo žensk pri reproduciranju svoje podrejenosti. Pravi, da se nikoli ni mogel načuditi temu, kar sam imenuje paradoks doxe, tj. da spoštujemo ureditev sveta skupaj z njegovimi odnosi vladanja, njegovimi privilegiji in krivica$\mathrm{mi}$, in da se to tako lahko vzdržuje na način, ki je sprejemljiv in celo naraven. Moška dominacija je oblika vladavine, ki je vpisana v vsaki družbeni ureditvi. Bourdieu poskuša razbiti »začarani krog legitimnosti« s tem, da pokaže, kako imamo pri moški dominaciji opraviti s popolnim preobratom vzrokov in posledic: družbeno postane naravno.

Kako se v zavesti lahko pojavi družbeni odnos dominacije, ki nastane $\mathrm{z}$ zamenjavo vzroka in posledice? Na kratko, s pomočjo miselnih struktur, ki organizirajo družbeno konstrukcijo sveta. V instrumentih našega spoznanja: v opazovanju, mišljenju, vrednotenju ali presojanju je vpisana, ali bolje rečeno, inkorporirana legitimnost moške dominacije, saj ženske sebe in moške ter svoj odnos do njih mislijo ravno preko teh instrumentov, tj. preko njih mislijo, opazujejo in presojajo svojo vrednost in vrednost tistih, ki vladajo. Ko ženske $v$ te instrumente spoznanja: v opazovanje, mišljenje, vrednotenje vključijo kategorije dojemanja, ali kategorije klasifikacije, ali nasprotne pole - kot strukture odnosov dominacije - takrat postane njihovo dejanje spoznanja neizbežno, dejanje priznavanja te dominacije in podrejenosti, tedaj same reproducirajo načelo ovekovečenja tega odnosa dominacije. Lastnost vladajočih je, da lahko (in moč imajo, da) svoj specifičen način obstoja, mišljenja, opazovanja in presojanja predstavijo kot univerzalen.

Onstran časa, ali bolje rečeno, nad njim, v bistvu najdemo iste klasifikacijske sheme, iste nasprotne pole, s pomočjo katerih mislimo razlike, miselne strukture, ki urejajo konstrukcijo sveta, ženske pa te klasifikacijske sheme, 
ki urejajo ali strukturirajo njihovo opažanje in mišljenje, uporabljajo na sebi, tako da odnose moči, v katere so ujete, mislijo in izražajo s stališča tistih, katerim so podrejene, kar jih vodi do samopodcenjevanja in samoočrnjevanja. Ženske so udejanjile svojo nemoč. Lastno negiranje je vpisano v najglobljo dispozicijo njihovega spolnega habitusa. Zato se Bourdieu zavzame za spoznavno revolucijo (Bourdieu, 1998, 10), saj načelo ovekovečenja odnosa domoinacije ne izhaja zgolj iz hišne skupnosti, temveč tudi iz šole, cerkve in države. Spoznavna revolucija je potrebna zato, da opravi spremembo pogojev proizvodnje znanja, in s tem tudi spremembo dispozicij habitusa.

Moč moških je prikrit, neviden, trajen odpor proti enakopravnosti žensk, ki prehaja preko vseh oblik moči, ki so vključene v njeno delegitimizacijo. Bourdieu v Preambuli k Moški dominaciji pravi: »Tudi sam sem vedno videl v moški dominaciji in načinu, na katerega se ta vzpostavlja in prenaša, odličen primer te paradoksalne podrejenosti, učinek tistega, kar imenujem simbolno nasilje, blago, neopazno, nevidno nasilje, ki je takšno tudi za njegove žrtve, kateremu je lastno, da se izvaja zgolj s pomočjo simbolne komunikacije in znanja, ali bolje rečeno, $\mathrm{z}$ neznanjem, priznanjem ali, na koncu koncev, občutenjem. Ta izjemno pogost družbeni odnos nam nudi izjemno priložnost, da dojamemo logiko dominacije, ki se izvaja v imenu simbolnih načel, ki jih poznajo in priznavajo tako vladajoči kot tudi podrejeni, ..." (Bourdieu, 1998, 7-8).

Četudi je moška dominacija nekoliko manj očitna, pa nekateri mehanizmi, na katerih temelji, še naprej funkcionirajo kot odnos krožne vzročnosti med dispozicijami in družbenimi pogoji za njihovo proizvodnjo (Bourdieu, 1998, 63). Očitna dolgotrajnost moške dominacije prispeva k temu, da zgodovinska konstrukcija pridobi značilnosti naravnega stanja in se tako ne izpostavlja tveganosti potrjevanja, $\mathrm{s}$ tem pa se vpiše $\mathrm{v}$ večnost narave (Bourdieu, 1998, 90). Zgodovinsko delo dehistorizacije, tj. pretvarjanje družbenih konstrukcij v naravne, pomeni neprekinjeno ponovno ustvarjanje objektivnih in subjektivnih struktur moške dominacije, ki se je nenehno ustvarjala, vse odkar obstajajo moški in ženske (ibid.). V zagotavljanje te kontinuitete se neprestano vključujejo agensi in institucije družine, cerkve, države, šole. Reprodukcija hierarhičnih dispozicij spodbuja ženske, da prispevajo $\mathrm{k}$ svojemu izključevanju $\mathrm{z}$ mesta, iz katerega so same v vsakem primeru izključene. 
Temu bi dodala še, da je Bourdieujevo ignoriranje razlikovanja med družbenim in biološkim spolom (postavljanje spola pod narekovaje) (Bourdieu, 1998, 91) razumljivo, če se zavedamo, da je v pojem habitusa vključena družbena konstrukcija, na katero se nanaša pojem (družbenega) spola, ki pa s procesom dehistorizcije postane »naraven «, na to pa se nanaša pojem (biološkega) spola. Oziroma, družbena konstrukcija je postala zgodovinsko nezavedno, v obliki dispozicij kot strukturirajoče strukture, tako da je potrebno izpeljati njihovo denaturalizacijo. To postane še bolj očitno, če vemo, da Bourdieu daje pojmom časovni pomen, ne pa brezčasnih biti ali bistev, in da je zanj pojem relativno pogojen s postopki objektivizacije (Pinto, 2002, 25), kar je še posebej očitno, ko analizira pojem daru ${ }^{5} \mathrm{v}$ simbolni ekonomiji.

Alain Touraine, ki v omenjeni knjigi analizira vedenje žensk, začne $s$ priznanjem, da je (družbeni) spol kreacija moške moči, in da mora ta pojem, ki je bil sicer koristen v boju proti esencializmu in naturalizmu, sam postati predmet kritike. Na ruševinah tega pojma, ki so ga tako energično zrušile radikalne feministke, zlasti skupina queer, se formirajo zelo različni pogledi (Touraine, 2006, 8).

Čeprav Bourdieu poudarja, da je glavna sprememba usmerjena na spremembo samopotrjujoče se, naravne legitimnosti, da se moške oblasti nima več za očitno in samoumevno (Bourdieu, 1998, 95), menim, da je njegov glavni prispevek v tem, da je pokazal na mehanizme, ki se ohranjajo skozi spremembe, in da je odgovoril na vprašanje (s katerim smo začeli to delo) zgodovinskega dela, ki je nujno, če hočemo iz zgodovine moške dominacij izluščiti tako mehanizme kot dejanja, ki so odgovorni za njeno dehistorizacijo (Bourdieu, 1998, 110).

Glavna kritika, ki leti na Bourdieuja, se nanaša na njegovo razumevanje družbenih determinizmov, ki pogojujejo podrejenost žensk. To lahko povzamemo z nekaj besedami, ki jih Alain Touraine pogosto ponavlja: »Ničesar ni mogoče narediti.« (Touraine, 2006, 11). Ali je potrebno, zato ker so v njej vpisani asimetrični odnosi spolov, binarne opozicije in dualizmi, izpeljati destrukcijo celotne človeške civilizacije?

5 Več o tem Filipović, M., 2004: »Društvena vremena i sociologija«, nekateri epistemološki aspekti v Glasniku, Odjeljenja društvenih nauka, CANU, št. 16, str. 285-300. 
Bourdieu vidi klice postmodernističnih filozofov po "preseganju dualizmov« (Bourdieu, 1998, 110) zavoljo njihove dekonstrukcije kot bahaštvo, saj spoli niso nastali kot preprosta posledica verbalnega poimenovanja, niti niso svobodne vloge, ki jih je mogoče prevzemati po lastni volji, ampak so vpisani v telesa in v svet, iz katerega črpajo svojo moč.

Jacques Derrida, profesor doktorskih ženskih študij na Univerzi $7 \mathrm{v}$ Parizu, na čigar ime se veže sam pojem dekonstrukcije, se je ukvarjal z raziskovanjem tekstov velikih filozofov, književnikov, lingvistov in psihoanalitikov tako, da jih je podvrgel dekonstrukciji. Pojem dekonstrukcije ima več pomenov, vendar se v glavnem nanaša na razgrajevanje ali natančno analizo pojmov ali tekstov. Dekonstrukcije se poslužujemo, da bi pokazali, kako so »naravne« dihotomije, kategorije poimenovanja in klasifikacijske sheme povezane in kako služijo določenim družbenim ali ekonomskim ciljem. Derrida pravi, da je potrebno pred vsako feministično politizacijo dekonstruirati to, kar sam imenuje falocentrično moč, ki pogojuje celotno naše kulturno nasledstvo. Sicer pa, niti Bourdieu niti Derrida (oba kot poststrukturalista, Bourdieu kot konstruktivistični strukturalist, Derrida kot dekonstrukturalist) ne verjameta, da bo feminizacija politične moči bistveno spremenila strukture dolge kontinuitete po Bourdieuju moške dominacije, ali po Deriddaju falocentrične moči moških.

Tem teoretičnim opcijam je skupno pretirano poudarjanje determiniranosti (ali struktur dolge kontinuitete) in zanemarjanje vpliva subjekta in možnosti, da lahko tako ženske kot tudi moški to usmerijo v več različnih smeri.

Alain Touraine meni, da je v sociologiji končano iskanje družbenih determinizmov in pregon ideje subjekta ter da se ideja subjekta dejansko ponovno vseprek vsiljuje. Pokazati hoče, da ženske oblikujejo neko novo kulturo (kar ni nova ideja, saj je na to opozoril že Marcuse), in dokazati nujnost prekinitve $\mathrm{z}$ diskurzom »tu ni moč ničesar storiti«.

Prevedla Martina Tekavec

Jezikovno pregledala Milica Antić Gaber 


\section{REFERENCE}

Bourdieu, P., »Le paradorxe du sociologue«. Sociologie et sociétés, vol. 11. št. 1, 1979, str. 85-94.

Bourdieu, P., Le sens pratique, Pariz, 1980.

Bourdieu, P., »Les chemins de la connaissance " Pogovor z Rogerjem Chartierjem, del: 1,2,3,4,5, Sociotoile, 1988.

Bourdieu, P., Wacquant, L., Reponses. Seuil, Pariz, 1992, str. 21.

Bourdieu, P., Vladavina muškarca, Podgorica, 2001.

Bourdieu, P., Science de la science et réflexivité. Raison d'agir., Pariz, 2001. (Slovenski prevod: Bourdieu, P., 2004: Znanost o znanosti in refleksivnost. Liberalna akademija, Ljubljana.)

Bourdieu, P., Interventions 1961-2001. Sciences sociales et action politique, Contre-feux, Agone, 2002.

Bourdieu, P., »Marcel Mauss aujourd 'hui«. Sociologie et sociétés, vol. 36, št. 2, 2004.

Corcuf, P., »Le collectif au défi du singulier: en partant de l'habitus". V Bernard Lahire (ur.): Le travail sociologique de Pierre Bourdieu, 1999, str. 95-121.

Derrida, J., »Koreografije«. Ženske studije, str. 1-11, prev. Arsić, B., URL: http://www.zenskestudie.edu.yu

Filipović, M., »Studije roda: dilema, izazov, mogućnost na Univerzitetu Crne Gore«. Zbornik Pravnog fakulteta u Podgorici, št. 31, 2000str. 31-37.

Filipović, M., Društvena moć žena u Crnoj Gori, Podgrica, 2003.

1998: Forum Pierre Bourdieu. Fnac St.Lazare, 5. oktober 1998.

Haraway, D., „Savoirs situés (la question de la science dans le feminisme et le privilegie de la perspective partielle)«. Dostopno: http://www.multitides. samizdat.net/article.php3?id-article $=1293$

Kamuf, P. »Dekonstrukcija i feminizam «, dostopono: http://www.zenstestudie.edu.yu

Pinto, L., Pierre Bourdieu et la théorie du monde sociale, Pariz, 2002.

Touraine, A., Le monde des femmes. Fayard, 2006.

Wacquant, L., »La vie sociologique de Pierre Bourdieu«. (V francoščino prevedla Catharine Lévy in avtor), International Sociology, ponovno natisnjeno v Politique, Revue européenne de debat, 2002. 


\section{LA DOMINATION MASCULINE DE PIERRE BOURDIEU}

Mots clés: domination masculine, epistémocentrisme, cercle vicieux, légitimité, habitus, champs

\section{Résumé}

L'objet de cet article est de mettre en evidence quelques questions soulevées par La domination masculine de Pierre Bourdieu: sa construction sociale, sa dehistorisation, et sa naturalisation, sa légitimité, la permanence dans les changements et la révolution dans la connaissance pour transformer le principe de la perpétuation caractérisant ce rapport de domination. 